\title{
Proximate composition of Bio Potential Seaweeds from Mandapam, South East Coast of India
}

\author{
S. Gokulakrishnan ${ }^{1 *}$, K. Raja ${ }^{1}$, G. Sattanathan ${ }^{2}$, J. Subramanian ${ }^{1}$ \\ ${ }^{1}$ Centre of Advanced Study in Marine Biology, Faculty of Marine Sciences, \\ Annamalai University, Parangipettai-608 502.Tamil Nadu, India \\ ${ }^{2} \mathrm{PG} \&$ Research Department of Zoology, Government College for Women (Autonomous), \\ Kumbakonam-612 001. Tamil Nadu, India \\ E-mail address: Corresponding author: gokul5564@gmail.com
}

Tel: 04144-243223; Fax: 04144-243553; Mobile: +91 9629910377

\section{Keywords: Seaweed, Nutrients, Seafood}

\begin{abstract}
Proximate composition of the three green seaweeds viz., Chaetomorpha aerea, Enteromorpha intestinalis, Enteromorpha compressa one brown seaweed Dictyota dichotoma and one red seaweed Gracilaria corticata was investigated by determination of protein, carbohydrates, lipid, moisture and ash content. In the present study, the total protein was recarded upper most in $E$. intestinalis and bare minimum in E. compressa. The maximum carbohydrates recorded in $C$. aerea and minimum in G. corticata. The lipid content was acquired upper limit in E. compressa and least in $C$. aerea. The ash and moisture content in following of 5 different seaweeds are as follows: $7.45 \mathrm{mg} / \mathrm{g}, 3.91 \mathrm{mg} / \mathrm{g}$ were recorded in the C. aerea, $8.52 \mathrm{mg} / \mathrm{g}, 3.42 \mathrm{mg} / \mathrm{g}$ in the E. intestinalis, $8.58 \mathrm{mg} / \mathrm{g}, 3.75 \mathrm{mg} / \mathrm{g}$ in the E. compressa, $9.47 \mathrm{mg} / \mathrm{g}, 4.23 \mathrm{mg} / \mathrm{g}$ in the D. dichotoma and $6.95 \mathrm{mg} / \mathrm{g}$, $3.98 \mathrm{mg} / \mathrm{g}$ in $G$. corticata. The proximate composition of 5 different seaweed species exhibited high nutritional value for human consumption.
\end{abstract}

\section{INTRODUCTION}

Seaweeds are an important source for food, fodder fertilizer and medicine from the ancient times. They are good sources of proteins, carbohydrates, vitamins and minerals in human nutrition. Seaweeds are the raw material for many industrial productions like agar-agar, alginate derivatives and carrageenan but they continue to be widely consumed as food in Asian countries. ${ }^{[1]}$ Nutrient content of seaweeds vary with species, geographical location, season, humidity and temperature. ${ }^{[2]}$ They are nutritionally valuable as fresh or dried vegetables, or as ingredients in wide prepared foods. ${ }^{[3]}$ In particular, certain edible seaweeds contain significant quantities of protein, lipids, minerals and vitamins. ${ }^{[4,5]}$ Many macroalgal species have been used as ingredients in both medicinal and food preparations, traditionally, in different regions across the world. ${ }^{[6,7]}$ There are 250 macro algal species which have been listed as commercially utilized worldwide, among which 150 are consumed as human food. ${ }^{[8]}$ Seaweeds are also considered as low calorie foods with high contents of minerals, vitamins, proteins and carbohydrates. Being rich in minerals, vitamins, trace elements and bioactive potential substances, seaweeds are called medical food of the $21^{\text {st }}$ century. ${ }^{[9]}$

Commercially available varieties of marine macroalgae are commonly referred to as 'seaweeds'. Macroalgae are classified as red algae (Rhodophyta), brown algae (Phaeophyta) or green algae (Chlorophyta), depending on pigmentation, morphological and anatomical characters. ${ }^{[10]}$ Red and brown algae are chiefly used as human food sources. ${ }^{[11]}$ The industrial applications of macroalgae are varied from each other and the by-products viz., polysaccharides are used in food, cosmetics, paint, crop, textile, paper, rubber and building industries. Additionally, seaweeds are used in medicine and in pharmacology for their antimicrobial, antiviral, antitumor, anticoagulant and brinolytic properties. Recently, abundant studies reported that Ulva can be of potential interest for food, development of novel drugs and functional foods, pharmaceutical and agricultural applications. ${ }^{[12,13]}$ 
Seasonal variation in growth and biochemical constitutions such as protein, carbohydrate and lipid in Hypnea valentiae, Acanthophora spicifera, Laurencia papillosa, E. compressa, Ulva lactuca and Caulerpa racemosa were observed for one year from Mandapam coast. ${ }^{[14]}$ Seasonal variation in biochemical constitutions of Sargassum wightii with special reference to yield in alginic acid content from Pudumadam has been reported. ${ }^{[15]}$ The objective of the present investigation was to evaluate the biochemical composition of the green algae C. aerea, E. intestinalis, E. compressa brown alga $D$. dichotoma and red alga $G$. corticata about their nutritional value of 5 different seaweeds of Mandapam coast, South east coast of India.

\section{MATERIALS AND METHODS}

\section{Collection of Seaweeds}

The green algae C. aerea, E. intestinalis, E. compressa brown alga D. dichotoma and red alga G. corticata were collected from the coastal region of Mandapam. The algal samples were brought to the laboratory using sterile polythene bags for biochemical characterization. Upon collection the samples were washed repeatedly under running tap water followed by distilled water twice to eliminate the adhering impurities. The samples were then air-dried prior proximate composition evaluation.

\section{Biochemical Analysis}

Estimation of total protein:

The total protein was estimated using the Folin-Ciocalteu Phenol method of Lowery et al. ${ }^{[16]}$ Estimation of total carbohydrates: et al. ${ }^{[17]}$

The total carbohydrate was estimated following the Phenol-sulphuric acid method of Dubois Estimation of total lipids:

The extraction of lipid was done by the chloroform-methanol mixture Folch et al. ${ }^{[18]}$

\section{RESULTS}

A highest and lowest level of protein was noticed as 24.52 and $15.69 \mathrm{mg} / \mathrm{g}$ in the $E$. intestinalis and E. compressa, carbohydrate of 56.78 and $27.57 \mathrm{mg} / \mathrm{g}$ in the E. compressa and $C$. aerea. Fat content of 21.25 and $11.67 \mathrm{mg} / \mathrm{g}$ in the C. aerea and G. corticata. The ash content of 9.42 and $6.59 \mathrm{mg} / \mathrm{g}$ in the $D$. dichotoma and G. corticata. Similarly the highest and lowest moisture level was recorded as 4.23 and $3.42 \mathrm{mg} / \mathrm{g}$ respectively in the $D$. dichotoma and E. intestinalis etc. Among the five different seaweeds studied, a higher level of ash and moisture of 9.47 and $4.23 \mathrm{mg} / \mathrm{g}$ was recorded in the $D$. dichotoma. The biochemical composition of the 5 different seaweeds are shown in Fig. 1 and the level of protein, carbohydrates, fat, ash and moisture content of the seaweeds are as follows 


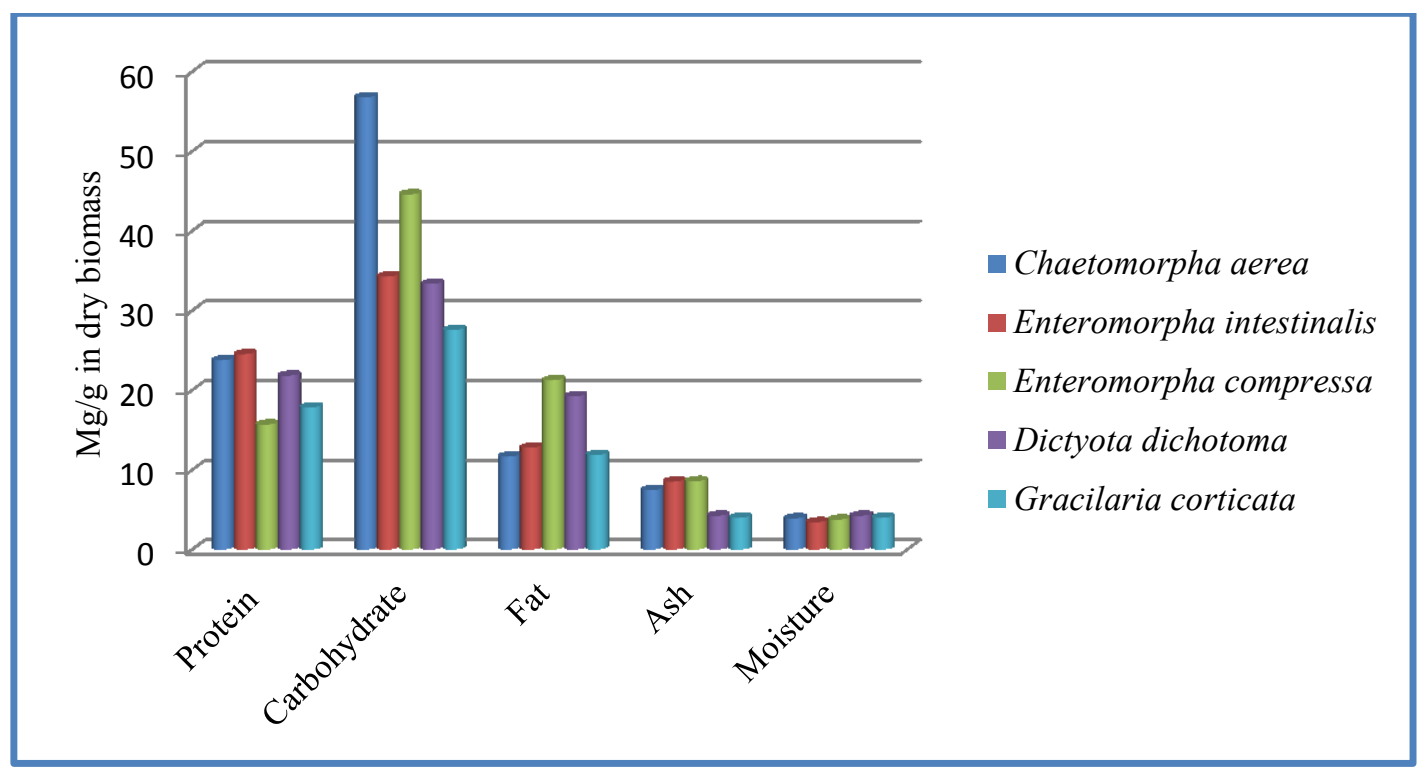

Fig. 1 Proximate composition of marine seaweeds

Proteins: E. intestinalis $(24.52 \mathrm{mg} / \mathrm{g})>$ C. aerea $(23.76 \mathrm{mg} / \mathrm{g})>$ D. dichotoma $(21.83 \mathrm{mg} / \mathrm{g})>$ G. corticata $(17.84 \mathrm{mg} / \mathrm{g})>$ E. compressa $(15.69 \mathrm{mg} / \mathrm{g})$.

Carbohydrates: C. aerea $(56.78 \mathrm{mg} / \mathrm{g})>$ E. compressa $(44.57 \mathrm{mg} / \mathrm{g})>$ E. intestinalis $(34.28 \mathrm{mg} / \mathrm{g})>$ D. dichotoma $(33.35 \mathrm{mg} / \mathrm{g})>$ G. corticata $(27.57 \mathrm{mg} / \mathrm{g})$.

Fat: E. compressa $(21.25 \mathrm{mg} / \mathrm{g})>$ D. dichotoma $(19.23 \mathrm{mg} / \mathrm{g})>$ E. intestinalis $(12.79 \mathrm{mg} / \mathrm{g})>$ G. corticata $(11.87 \mathrm{mg} / \mathrm{g})>$ C. aerea $(11.67 \mathrm{mg} / \mathrm{g})$.

Ash: D. dichotoma $(9.47 \mathrm{mg} / \mathrm{g})>$ E. compressa $(8.58 \mathrm{mg} / \mathrm{g})>$ E. intestinalis $(8.52 \mathrm{mg} / \mathrm{g})>$ C. aerea $(7.45 \mathrm{mg} / \mathrm{g})>$ G. corticata $(6.95 \mathrm{mg} / \mathrm{g})$.

Moisture: D. dichotoma $(4.23 \mathrm{mg} / \mathrm{g})>$. corticata $(3.98 \mathrm{mg} / \mathrm{g})>$ C. aerea $(3.91 \mathrm{mg} / \mathrm{g})>$ E. compressa $(3.75 \mathrm{mg} / \mathrm{g})>$ E. intestinalis $(3.42 \mathrm{mg} / \mathrm{g})$.

\section{DISCUSSION}

Among the five different seaweeds studied, a higher level of ash and moisture of 9.42 and $4.23 \mathrm{mg} / \mathrm{g}$ recorded in the seaweed $D$. dichotoma. Subsequently, the biochemical composition of selected marine seaweeds are shows rich amount of fat and protein contents of 56.78 and 24.52 $\mathrm{mg} / \mathrm{g}$ which were recorded in the seaweeds viz., C. aerea and E. intestinalis etc., The above parameters are in merge (10-29\%) previously reported on Ulva pertusa, Ulva sp. U. lactuca and Ulva rigida. ${ }^{[19,20,21,22]}$ A smaller level of protein contents $(7.1-8.5 \%)$ was recorded in $U$. lactuca in the northeast of Hong Kong and in Tunisia. ${ }^{[5]}$ However, presence of highest protein content of $21.25 \mathrm{mg} / \mathrm{g}$ recorded in the E. intestinalis of our study is considered as important criteria. ${ }^{[23]}$ Moreover, the variations recorded in the previous research in the same line are due to seasonal changes at the different coastal areas. Nirmal kumar et al., were registered the lowest level of protein concentration than our investigated selected seaweed. This seaweeds were ranged from 0.429 to $1.8887 \mathrm{mg} / \mathrm{g}$; highest protein was registered in G. corticata $(1.8887 \mathrm{mg}$ ) followed by Padina boergesenii (1.8392) and Monostroma latissimum (1.384), C. indica (1.367), S. cinctum (1.2507). Whereas the lowest protein content was recorded from Sargassum tenerrimum (0.429) followed by Dictyopteris acrostichoides $(0.4235)$, T. ornate (0.4939) and D. dichotoma (0.7777). The protein content of seaweed varieties varies greatly and depends on such factors as season and environmental growth conditions. ${ }^{[24]}$ 
In general, the carbohydrate is the most important elements for metabolism as it supplies the energy needed for respiration and other metabolic processes in human diet. Murugaiyan et al., were

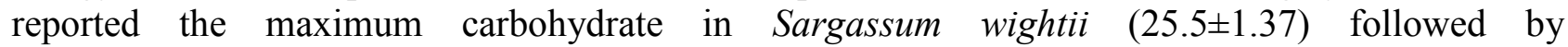
Stoechospermum marginatum (15.8 \pm 0.8$)$ and Caulerpa taxifolia $(9.7 \pm 0.47)$ and the minimum carbohydrate content was found in Caulerpa racemosa $(8.5 \pm 0.84) .{ }^{[25]}$ Siddique et al., were estimated the carbohydrate level is $40.64 \%$ in sub-tropical red seaweed of Gelidium pusillum. ${ }^{\text {[26] }}$ The Carbohydrate concentration was high in previously recorded $33.38 \%$ in seaweed Sargassum myriocystum. ${ }^{[27]}$ Ricketts observed that carbohydrate level 5-57\% of various golden brown algae in dry weight basis. Carbohydrate contents must appear that be very variable depending upon the state of nutrition cells. Presence of highest carbohydrate content of $56.78 \mathrm{mg} / \mathrm{g}$ in the seaweed C. aerea and a minimum of $27.57 \mathrm{mg} / \mathrm{g}$ in $G$. corticata of the current study closely resemble with the previous work carried out in this line. ${ }^{[28]}$

In general, the lipid provides very much level of energy in oxidation process than other biological compounds. They comprise as a storage material for living organisms. In macro algae lipids are widely spread in world-wide. [29] Many researchers previously observed the lipid concentration on some algal species. Murugaiyan et al., were studied the lipid concentration on Stoechospermum marginatum (3.58\%) and minimum lipid level was observed in Caulerpa racemosa $(0.9 \%) .{ }^{[26]}$ Although, according to the previously reported values in the literature, most of the macro algae are covered lipid lesser value than $4 \%$ DW however, some macroalgae had higher amount of crude lipid such as Dictyota acutiloba (16.1\% DW) and D. sandvicenis $(20.2 \%$ DW). ${ }^{[30]}$ The measured lipid contents in the present study are in consistency with that reported in Caulerpa racemosa, and Padina gymnospora, $19.1 \%$, and $11.4 \%$, respectively However, they are upper than those determined previously for Ulva lactuca, (7.87-1.64 \% DW) and (0.3-1.64\% dry weight $).{ }^{[22,23,31]}$ Presence of highest fat content of $21.25 \mathrm{mg} / \mathrm{g}$ in the seaweed $E$. compress $a$ and a minimum of $11.67 \mathrm{mg} / \mathrm{g}$ in $C$. aerea of the current study closely depicting with the previous work carried out in this line.

Mohammadi et al., were investigated the ash content on green seaweed and brown seaweed of Ulva rigida, Codium bursa, Cystoseira barbata and Ceramium diaphanum having 25.74\%, 29.08\%, 14.24\%, 11.35\% respectively. ${ }^{[32]}$ Pattama Ratana-arporn and Anong Chirapart were reported that Caulerpa lentillifera and Ulva reticulata containing $24.21 \%$ and $17.58 \%$ of ash content. Himanthalia elongata (26.78\%), Laminaria ochroleuca $(29.47 \%)$ and Porphyra sp. (19.07\%). ${ }^{[33]}$ Contrarily, highest and least ash content of 9.42 and $6.59 \mathrm{mg} / \mathrm{g}$ were noticed in the D. dicotoma and G. corticata respectively and the results obtained in the present study is not correlating with any of previous work carried out in the biochemical studies of seaweeds. Generally, the ash content of seaweeds is much higher than those of terrestrial vegetables other than spinach. ${ }^{[34]}$ The variability of ash content among the studied algae was related to the capacity of each species to accumulate minerals according to environmental conditions, seasons and geographical location. ${ }^{[2,35]}$

The moisture content noticed in the present study varied from 3.42 to $4.23 \mathrm{mg} / \mathrm{g}$ as resembling with the studies conducted previously in some similar line (other algal species). The moisture content of the fresh seaweed samples ranged between 75.95 and $96.03 \%$. Fisal Ahmad et al., were investigated the moisture content among the 9 different red seaweeds. ${ }^{[36]}$ The Laurencia sp. was found to have the highest moisture content (96.03\%) followed by Laurencia sp. (93.59\%), Gracilariaverrucosa (85.45\%), Eucheumadenticulatum (84.54\%), Kappaphycus alvarezii (aringaring) (79.78\%), Kappaphycus striatum var. sacol (79.70\%), K. striatum var. sacol (76.69\%) and K. striatum var. sacol $(75.95 \%)$. The moisture concentration obtained in $C$. racemosa was close to the values previously reported and these consequences were might be due to the influence of many abiotic factors such as atmosphere, geography and season. ${ }^{[37,38]}$ 


\section{CONCLUSION}

The study revealed seaweed can also be used as an organic ingredient in some of the food products in the food industry. Seaweeds could be used as a major feed ingredient in the (alternative feed) aquaculture as well as poultry industry. It is suggested that the cultivation of seaweeds at larger scale in the barren long coastal line of our country augment economy and employment opportunities through setting up of small scale seaweed based units to the coastal area people. By establishing such small scale seaweed production units would immensely helpful in producing the bio-fuel to boost up Indian economy.

\section{ACKNOWLEDGEMENT}

We are thankful to the Dean, CAS in Marine Biology, Faculty of Marine Sciences, Annamalai University, Parangipettai for the facilities provided. Authors are grateful to Ministry of Human Resource Development (MHRD), Govt. of India for financial support.

\section{References}

[1] Mishra V K, Temelli F, Ooraikul B, Shacklock P F, Craigie J S. Lipids of the red alga, Palmaria palmata, Bot. Mar., 36 (2), 169-174, 1993.

[2] Kachler S, Kennish R. Summer and winter comparisons in the nutritional value of marine macroalgae from Hong Kong. Botanica Marina, 39: 11-17, 1996.

[3] Robledo D, Pelegrin Y F. Chemical and Bull mineral composition of edible seaweed species Yucatan. Botanica Marina, 45: 58-65, 1997.

[4] Norziah M H, Ching Ch Y, Nutritional composition of edible seaweeds Gracilaria changgi. Food Chemistry, 68: 69-76, 2002.

[5] Wong K H, Cheung P C K. Nutritional evaluation of some subtropical red and green seaweeds. Part I-proximate composition, amino acid profiles and some physic - chemical properties. Food Chemistry, 71: 475-482, 2000.

[6] Cardozo K H M, Guaratini T, Barros M P. Metabolites from algae with economical impact. Comparative Biochemistry and Physiology: Part C Vol.146: 60-78, 2007.

[7] Chandini S K, Ganesan P, Suresh P V. Seaweeds as source of nutritionally beneficial compounds- review. Journal of Food Science and Technology: Vol.45 (1) 1-13, 2008.

[8] Barrow C J. Marine by-products as functional food ingredients. Food technology international, 1-5, 2007.

[9] Khan S I, Satam S B. Seaweed mariculture: Scope and potential in India. Aquaculture Asia: Vol.8, 26-29, 2003.

[10] Manivannan K, Thirumaran G, Karthikai Devi G, Anantharaman P, Balasubramanian T. Proximate composition of different groups of seaweeds from Vedalai coastal waters (Gulf of Mannar): southeast coast of India, Middle-East, J. Sci. Res., 4 (2), 72-77, 2009.

[11] Dawczynski C, Schubert R, Jahreis G, Amino acids, fatty acids, and dietary fibre in edible seaweed products, Food Chem, 103 (3), 891-899, 2007.

[12] Costa L S, Fidelis G P, Cordeiro S L, Oliveira R M, Sabry D A. Biological activities of sulfated polysaccharides from tropical seaweeds. Biomed Pharmacother 64: 21-28, 2010.

[13] Wijesekara I, Pangestuti R, Kim S K. Biological activities and potential health benefits of sulfated polysaccharides derived from marine algae. Carbohyd. Polym., 84: 14-21, 2011. 
[14] Kaliaperumal N, Ramalingam J R, Kalimuthu S, Ezhilvalavan R. Seasonal changes in growth, biochemical constituents and phycocolloid of some marine algae of Mandapam coast. Seaweed Research and Utilisation, 24(1): 73-77, 2002.

[15] Reeta Jayasankar, Ramalingam J R, Kaliaperumal N. Biochemical composition of some green algae from Mandapam coast. Seaweed Research Utilisation, 12 (1and2): 37-40, 1990.

[16] Lowry O H, Rosebrough N J, Farr A L, Randall R J. Protein measurement with the folin phenol reagent. J. Biol Chem, 193: 265-273, 1951.

[17] Dubois M, Gilles K A, Hamilton J K, Rebers P A, Smith F. Colorimetric method for determination of sugar and related substances. Annal Chem, 28: 350, 1956.

[18] Folch J, Lees M, Sloane Stanley G H. A simple method for the isolation and purification of total lipids from animal tissues. J. Biol Chem, 226: 497-509, 1957.

[19] Fleurence J. Seaweed proteins: biochemical nutritional aspects and potential uses. Trends in Food Sci and Technol 10: 25-28, 1999.

[20] Fujiwara-Arasaki F T, Mino N, Kuroda M. The protein value in human nutrition of edible marine algae in Japan. Hydrobiologia 116/117: 513-516, 1984.

[21] Valente L M P, Gouveia A, Rema P, Matos J, Gomes E F, Pinto I S. Evaluation of three seaweeds Gracilaria bursa-pastoris, Ulva rigida and Gracilaria cornea as dietary ingredients in European sea bass (Dicentrarchus labrax) juveniles. Aquaculture, 252: 85-91, 2006.

[22] Ortiz J. Romero N, Robert P, Araya J, Lopez-Hernández J, Bozzo C E, Navarrete C E, Osorio A, Rios A. Dietary fiber, amino acid, fatty acid and tocopherol contents of the edible seaweeds Ulva lactuca and Durvillaea antarctica. Food Chemistry, 99: 98-104, 2006.

[23] Yaich H, Garna H, Besbes S, Paquot M, Blecker C, Attia H. Chemical composition and functional properties of Ulva lactuca macroalgae collected in Tunisia. Food Chemistry, 128: 895-901, 2011.

[24] Nirmal kumar J I, Megha barot, Rita N. Kumar. Phytochemical analysis and antifungal activity of selected seaweeds from okha coast, gujarat, india. 2014.

[25] Murugaiyan K, Narasimman S, Anatharaman P. Proximate composition of marine macro algae from Seeniappa Dharka, Gulf of Mannar region, Tamil Nadu. International Journal of Research in Marine Sciences, 1(1): 1-3, 2012.

[26] Siddique M A M, Khan M S K, Bhuiyan M K A. Nutritional composition and amino acid profile of a sub-tropical red seaweed Gelidium pusillum collected from St. Martin's Island, Bangladesh. International Food Research Journal, 20(5): 2287-2292, 2013.

[27] Kokilam Ganapathi, Vasuki Subramanian, Suja Mathan. Bioactive potentials of brown seaweeds, sargassum myriocystum j. Agardh s. Plagiophyllum c.agardh and s.ilicifolium (turner) j. Agardh. Int. Res j pharm. App sci, 3(5):105-111, 2013.

[28] Ricketts T R. On the chemical composition of some unicellular algae. Phytochem, 5: 67-76, 1966.

[29] Miller J P A. Fats Steroids. In: Physiology and Biochemistry of Algae. Lewin RA (Ed.), Academic Press, New York. 92p, 1962.

[30] McDermid K J, Stuercke B. Nutritional composition of edible Hawaiian seaweeds. Journal of Applied Phycology, 15, 513-524, 2003.

[31] Rameshkumar S, Ramakritinan C M, Eswaran K, Yokeshbabu M. Proximate composition of some selected seaweeds from Palk bay and Gulf of Mannar, Tamilnadu, India. Asian Journal of Biomedical and Pharmaceutical Sciences, 3(16):1-5, 2012. 
[32] Mohammadi M, Tajik H, Hajeb P. Nutritional composition of seaweeds from the Northern Persian Gulf. Iranian Journal of Fisheries Sciences, 12(1) 232- 240, 2012.

[33] Pattama Ratana-arporn, Anong Chirapart. Nutritional Evaluation of Tropical Green Seaweeds Caulerpa lentillifera and Ulva reticulate. Kasetsart J. (Nat. Sci.), 40: 75 - 83, 2006.

[34] Sanchez-Machado D I, Lopez-Cervantes J, Lopez-Hernandez J, Paseiro-Losada P. Fatty acids, total lipid, protein and ash contents of processed edible seaweeds. Food Chemistry, 85: 439444, 2004.

[35] Polat S, Ozogul Y. Biochemical composition of some red and brown macroalgae from the northeastern Mediterranean Sea. Int. J. Food Sci. Nutr, 59: 566-572, 2008.

[36] Fisal Ahmad, Mohd Rosni Sulaiman, Welzan Saimon, Chye Fook Yee, Patricia Matanjun. Proximate compositions and total phenolic contents of selected edible seaweed from semporna, sabah, malaysia. Borneo science, 31, 2012.

[37] Kumar M, Gupta V, Kumari P, Reddy C R K, Jha B. Assessment of Nutrient Composition and Antioxidant Potential of Caulerpaceae Seaweeds. Journal of Food Composition and Analysis, 24 (2): 270-278, 2011.

[38] Mendis E, Kim S K. Present and Future Prospects of Seaweeds in Developing Functional Foods. In Advances in Food and Nutrition Research, Volume 64: Marine Medicinal Foods; Implications and Applications, Macro and Microalgae. Elsevier Inc, USA. 1-13, 2011. 